\title{
Most promising solid dispersion technique of oral dispersible tablet
}

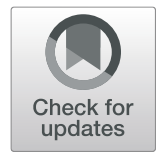

Vikrant K. Nikam ${ }^{1 *}$, Shubham K. Shete ${ }^{1}$ and Jyoti P. Khapare ${ }^{2}$

\begin{abstract}
Background: The most common problem about conventional dosage form is dysphagia (difficulty in swallowing). So, we design a new approach in a conventional dosage form which is oral dispersible tablet. Oral dispersible tablet is also called as mouth dissolving tablet, fast dissolving tablet, or oral disintegrating tablet. Oral dispersible tablet has advantage as it quickly disintegrates into saliva when it is put on the tongue. The faster the drug disintegrates or is dissolved, the faster the absorption and the quicker the therapeutic effect of drug will be attained.

Main text: This review article focuses on the progress in methods of manufacturing and various latest technologies involved in the development of oral disintegrating tablet. The solid dispersion technique is one of the novel techniques to manufacturing the oral dispersible tablet. Solid dispersion is basically a drug polymer two component system.

Conclusion: This review article focuses on advantages, disadvantages, materials used as carrier for solid dispersions, methods of preparation of solid dispersion, classification of solid dispersion, promising drugs that can be incorporated into oral disintegrating tablet by solid dispersion techniques, and recent research in solid dispersion technique using polymers as carriers.
\end{abstract}

Keywords: Solid dispersion, Disintegration, Dissolution, Oral dispersible

\section{Background}

Now a day, tablet is a one of the most popular dosage form among all dosage form due to the advantage of its convenience of easy to administration and easy preparation procedure [1]. Oral disintegrating tablet forms are easy to disintegrate, dissolved by saliva in the mouth. Oral disintegrating tablet are useful in all types of patients like pediatric, geriatric, bedridden, mentally disabled, and the patient with dysphagia problem for conventional dosage form. Oral dispersible tablet are also used when local action in the mouth is desirable for example, local anesthetics for toothaches, mouth ulcers, cold sores, and to those who suffered from "dysphagia" for sustained action tablet or capsule [2]. So, one attempt is made towards to increase the solubility of certain class of drug. One of the most commonly used methods to increase disintegration

\footnotetext{
* Correspondence: vikrantnikam@gmail.com

${ }^{1}$ Amrutvahini College of Pharmacy, Sangamner, MS 422 608, India Full list of author information is available at the end of the article
}

and bioavailability of that class of drug is the solid dispersion technique. Solid dispersion technique is the most useful method to increase the disintegration and its dissolution, as well as decrease their dosing frequency; therefore, toxicity also gets reduced. Solid dispersion technique has been used as the most useful method to increase the solubility property and bioavailability of certain classes of drugs [3].

\section{Main text}

\subsection{Solid dispersion}

Chiou and Reigelman first defined solid dispersion as "dispersion of one or more active ingredients in an inert carrier or matrix (hydrophilic) at solid state prepared by fusion, solvent or melting solvent method" [4-6], or solid dispersion defined as "a dispersion that include the formation of eutectic mixtures of drug with carriers that soluble in water easily by melting of their physical mixtures" $[7,8]$.
Springer Open
(๑) The Author(s). 2020 Open Access This article is licensed under a Creative Commons Attribution 4.0 International License, which permits use, sharing, adaptation, distribution and reproduction in any medium or format, as long as you give appropriate credit to the original author(s) and the source, provide a link to the Creative Commons licence, and indicate if changes were made. The images or other third party material in this article are included in the article's Creative Commons licence, unless indicated otherwise in a credit line to the material. If material is not included in the article's Creative Commons licence and your intended use is not permitted by statutory regulation or exceeds the permitted use, you will need to obtain permission directly from the copyright holder. To view a copy of this licence, visit http://creativecommons.org/licenses/by/4.0/. 
Table 1 Carriers used in solid dispersion

\begin{tabular}{|c|c|c|c|}
\hline $\begin{array}{l}\text { Sr. } \\
\text { No }\end{array}$ & Category & Carriers & Examples \\
\hline 1 & Sugars & Dextrose, sucrose, galactose, sorbitol, maltose, etc. & Rofecoxib \\
\hline 2 & Acids & Citric acid, succinic acid, etc. & Felodipine \\
\hline 3 & Polymers & $\begin{array}{l}\text { PVP, PEG, HPMC, hydroxy ethyl cellulose, cyclodextrins, pectin, } \\
\text { galactomanan, etc. }\end{array}$ & $\begin{array}{l}\text { Temazepam, } \\
\text { troglitazone, etc. }\end{array}$ \\
\hline 4 & Insoluble or enteric polymer & $\begin{array}{l}\text { HPMC pthalate, Eudragit L100, Eudragit E100, Eudragit RL, } \\
\text { Eudragit RS, etc. }\end{array}$ & Indomethacin \\
\hline 5 & Surfactants & $\begin{array}{l}\text { Polyoxyethylene stearate, poloxamer 188, deoxycholic acid, } \\
\text { Tweens, spans, etc. }\end{array}$ & Felodipine \\
\hline 6 & Miscellaneous & $\begin{array}{l}\text { Pentaerythritol, pentaerythritol tetraacetate, urea, urethane, } \\
\text { hydroxy alkyl xanthins, etc. }\end{array}$ & Rofecoxib \\
\hline
\end{tabular}

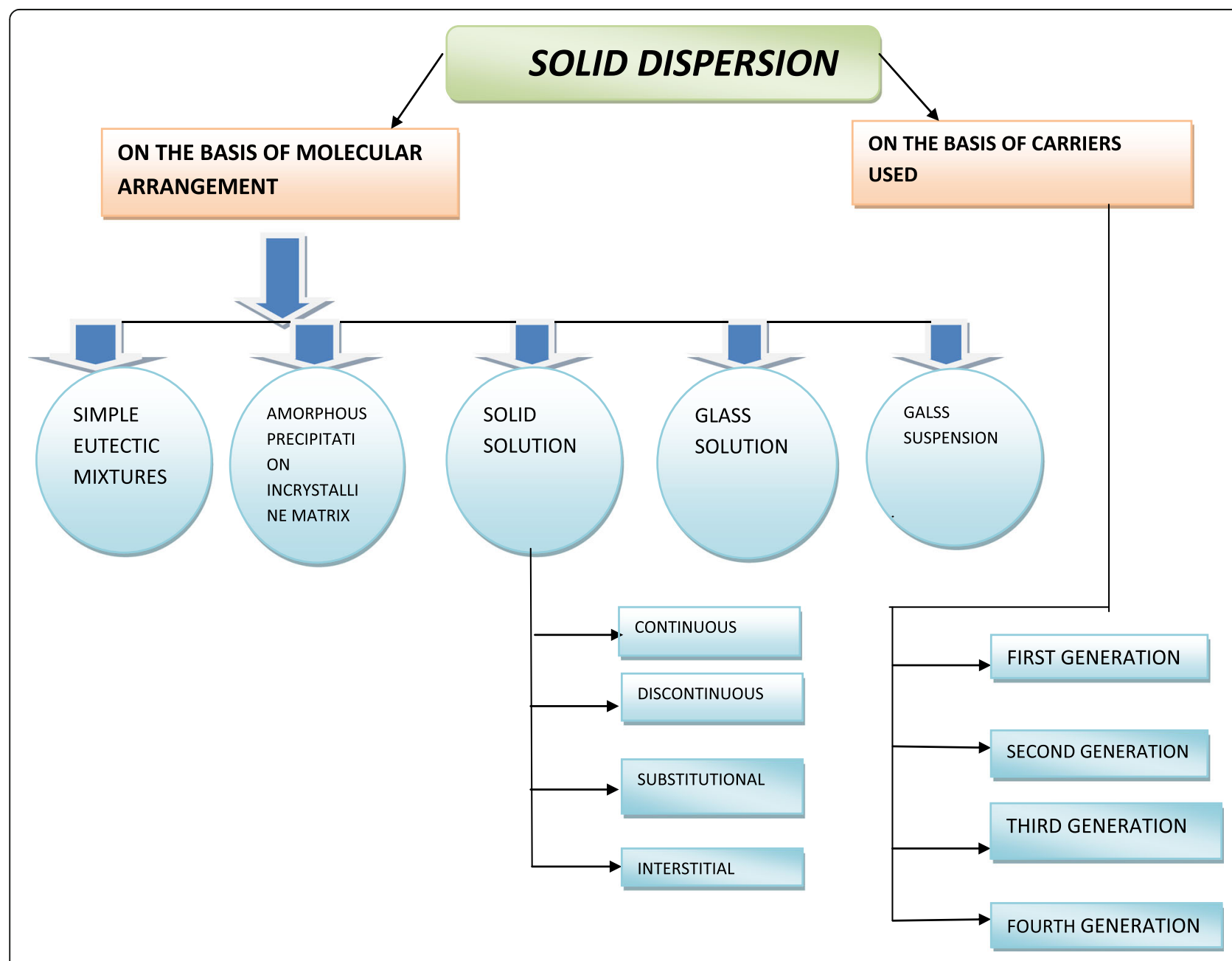

Fig. 1 Classification of solid dispersion 


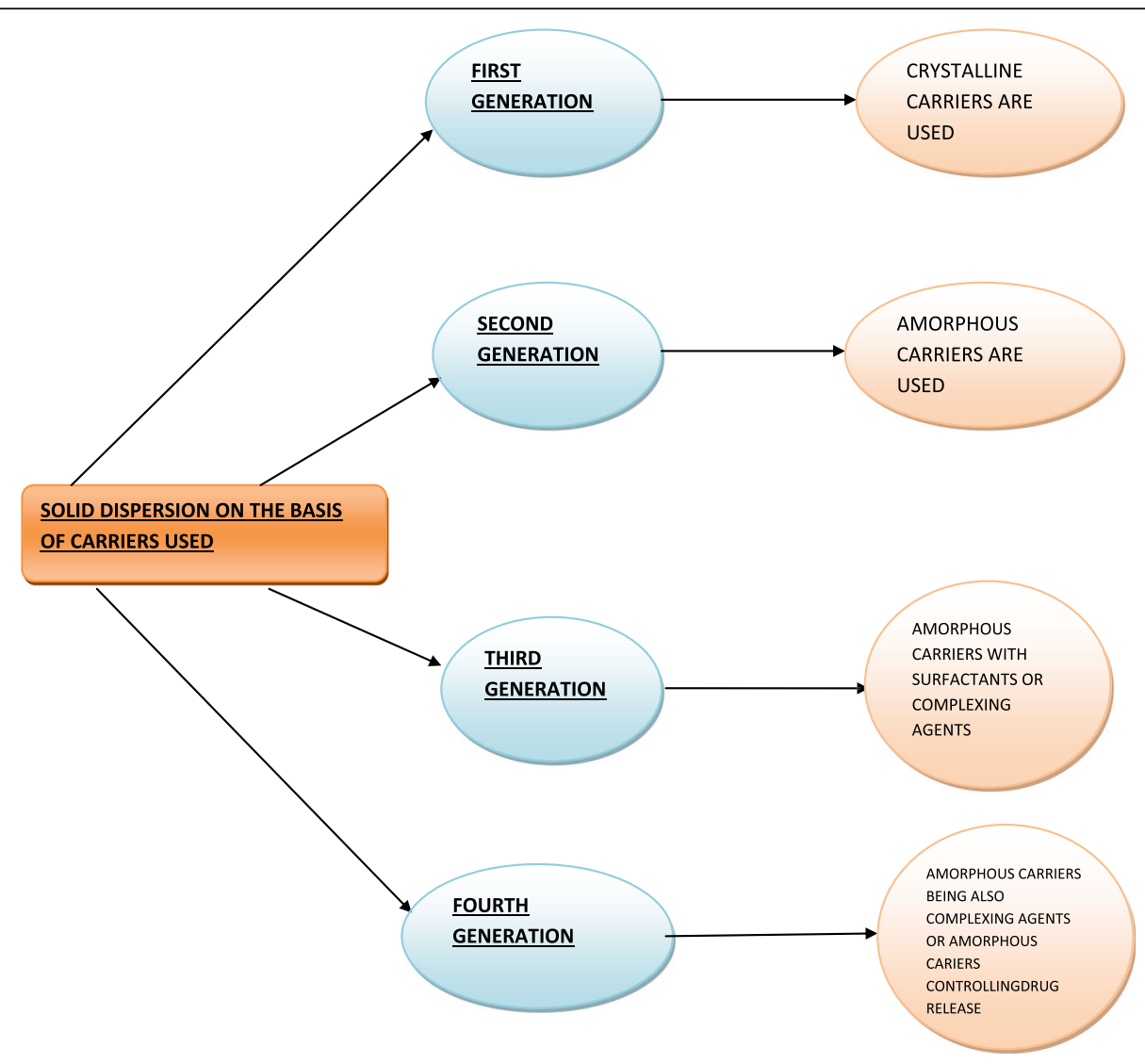

Fig. 2 Classification of solid dispersion on based on use of carriers

\subsection{Merits of solid dispersion}

1 Carrier which is used in formulation that reduces particle size so that increases solubility due to high surface area [9-11].

2 When the wettability of drug candidate is increased, the dissolving property also increased. Solid dispersion increases the wettability of drug $[9,11]$.

3 Solid dispersion is responsible for increasing porosity of drug. This characteristic of drug is also responsible for improving solubility $[9,12,13]$.

4 Solid dispersion is responsible for converting insoluble drug into the amorphous state which is responsible for higher degree of dissolution. The drug candidates in its amorphous state are easy to release because no energy is required for breaking the crystal lattice in dissolution process $[9,14,15]$.

5 Use of hydrophilic carrier like PEG and use of superdisintegrant like croscarmellose sodium is used in manufacturing of oral disintegrating tablet by solid dispersion technique which are responsible for increasing aqueous dissolution $[7,16]$.

\subsection{Demerits of solid dispersion}

1 Solid dispersion have drawback like poor scale-up for the manufacturing [7].

2 Sometimes it is difficult to handle due to tackiness problem [9].

3 Major disadvantage of solid dispersion technique is instability. Reason behind it is that most of the carriers used in formulation are polymers which can easily absorb the moisture due to this phase separation occurs which is responsible for instability [17-19].

4 Recrystallization of the amorphous drug and/or transitions occurs between polymers responsible for stability problems $[18,19]$.

Carriers used in solid dispersion for improving dissolution rate $[11,18]$ are found in Table 1.

Classification of solid dispersion [4] is shown in Fig. 1.

\section{On the basis of molecular arrangements [4]} 3.1 Simple eutectic mixtures

This type of solid dispersion is formed by fast solidification of molten state of drug and polymer which do not 


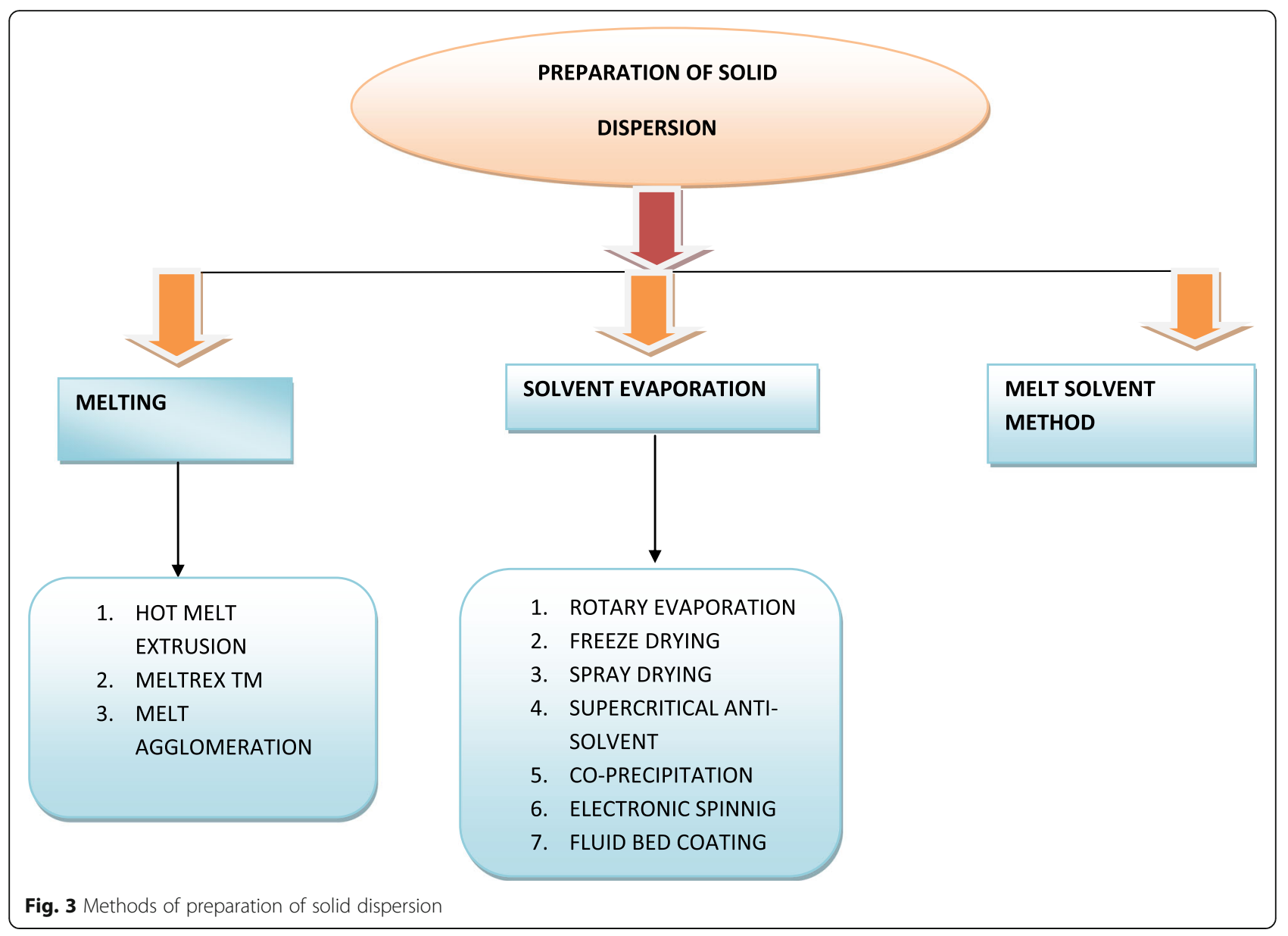

Melting of drug and carrier together

(Above eutectic point)

Cooled or solidify

Fig. 4 Process of melting method

Final mass is crushed, then pulverized and sieved 


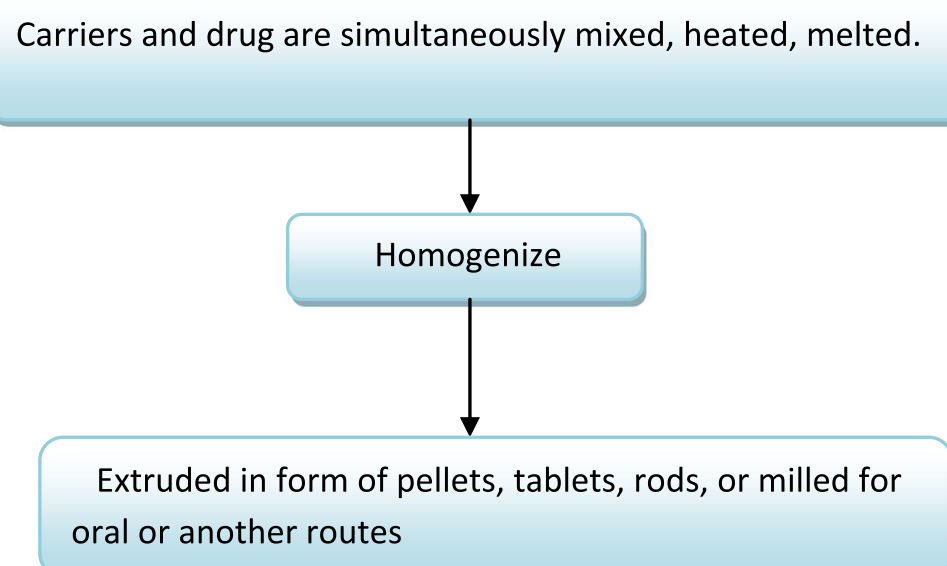

Fig. 5 Process of hot stage extrusion

have miscibility when they try to crystallize just like two different components. It shows the increase in release pattern due to fine crystals, and it also shows increase in wettability due to the presence of carriers like polymers Eudragit EPO, PEG, etc.

\subsection{Amorphous precipitation in crystalline matrix}

It is the same as simple eutectic mixture but have minute difference as follows:

Amorphous precipitation method gives drug in precipitated form, and simple eutectic mixtures gives drug in crystalline form.

\subsection{Solid solution}

This type of solid dispersion is miscible in its solid state and also in its fluid state. It gives either crystalline or amorphous type. The major advantage of this type is a better dissolution rate compare to the eutectic mixture more reduced particle size of the drug. Dissolution rate of drug depends on dissolution of carriers.

\subsubsection{Continuous type}

This type of solid dispersion concern about strength of bonding between the components i.e. individual component strength of bonding is weaker than the two component strength of bonding.

\subsubsection{Discontinuous type}

This type of solid dispersion concern about the component solubility, i.e., each of the components had limited solubility in the other component.

\subsubsection{Substitutional solid solution}

In this type, one solvent molecule is substituted by another solute molecule in the crystal lattice.

\subsubsection{Interstitial solid solutions}

In this type of solid dispersion, interstitial space of the solvent lattice is replaced by the solute molecule.

\section{Based on hot melt extrusion}

Which reduced residence time of drug and excipients in extruder so avoid the oxidation and hydrolysis

Fig. 6 Process of Meltrex TM 


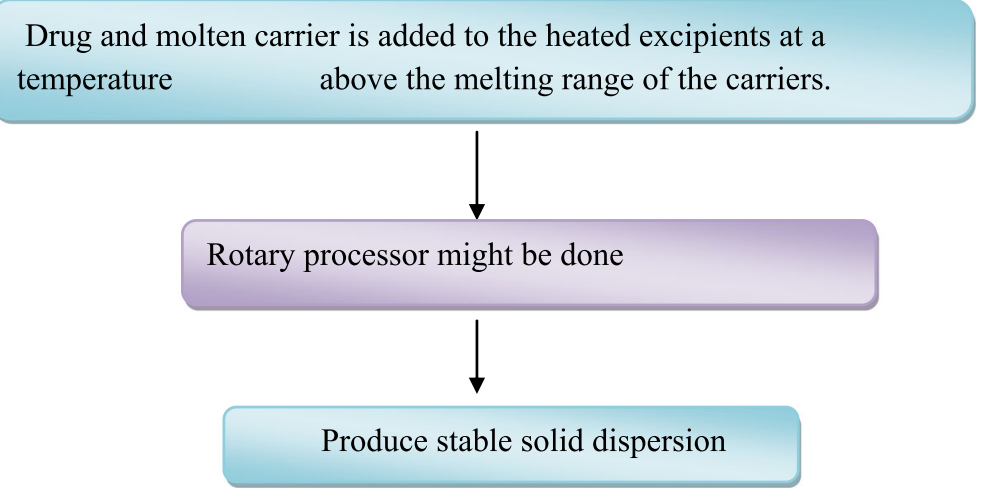

Fig. 7 Process of melt agglomeration

\section{On the basis of carriers used in solid dispersion $[18,20]$ (Fig. 2)}

\subsection{Methodology used or techniques of preparation of} solid dispersion

There are many methods developed for preparation of solid dispersions, these methods are based on the challenge of mixing of carriers and a drug [7] (Fig. 3).

\subsubsection{Melting method [21]}

Another name of this method is a fusion method. This method includes sulfathiazole and urea as a matrix which was melted with drug followed by cooling step (Fig. 4).

4.1.1.1 Merits This method does not require any solvent.

\subsubsection{Demerits}

1 Drug degradation occurs due to high temperature.

2 Incomplete miscibility between drug and polymer due to viscosity.

3 Phase separation also occurs during cooling step.

For overcoming these demerits, the following methods are designed:

\subsubsection{Hot stage extrusion [22]}

This method include the technique where the drug and carriers are simultaneously mixed, heated, melted, homogenized, and extruded into rods, tablets, milled or pellets. The merit of this technique is that it avoids the degradation of drug during the melting (Fig. 5).

\subsubsection{Meltrex TM [23]}

This type of solid dispersion method is patented and based on the hot melt extrusion principle. This technique is associated with special extruder with two screw and two independent hoppers which can vary the temperature over a broad range which reduces residence time of the drug in the extruder and avoid thermal stress to the drug and excipients. The major advantage of this technique is that it protects drug candidate from the oxidation and hydrolysis by complete removal of oxygen and moistures (Fig. 6).

\subsubsection{Melt agglomeration [24]}

This technique is based on conventional high shear mixers. This solid dispersion technique involves carrier as a binder and process followed by addition of drug with molten carriers to the heated excipients at a

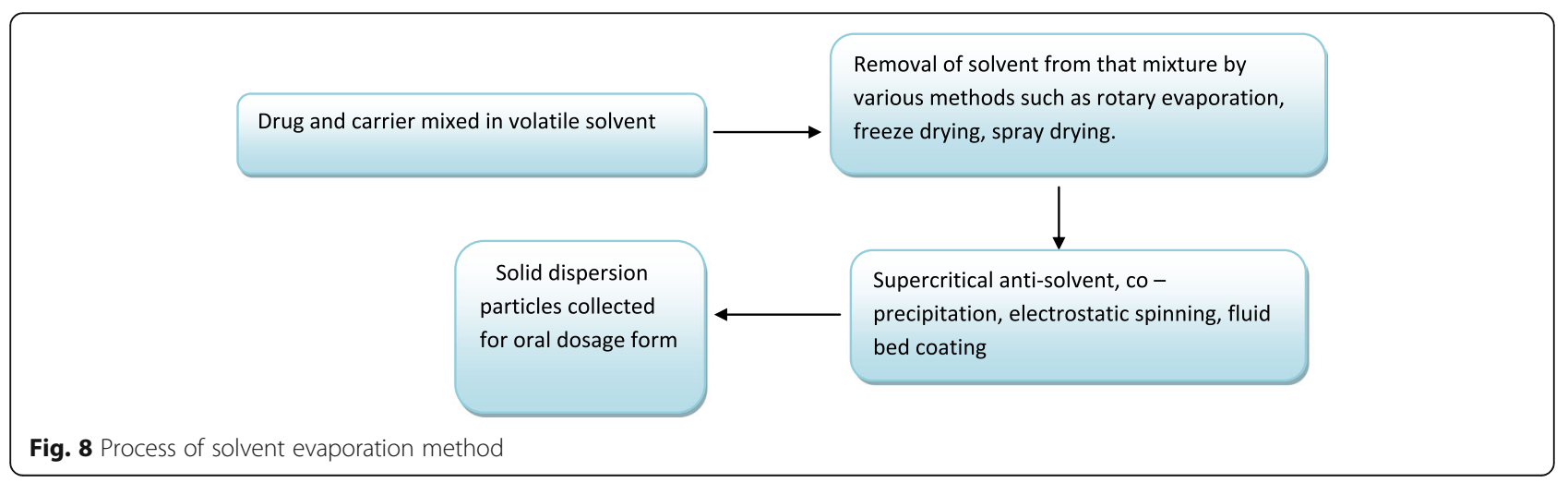




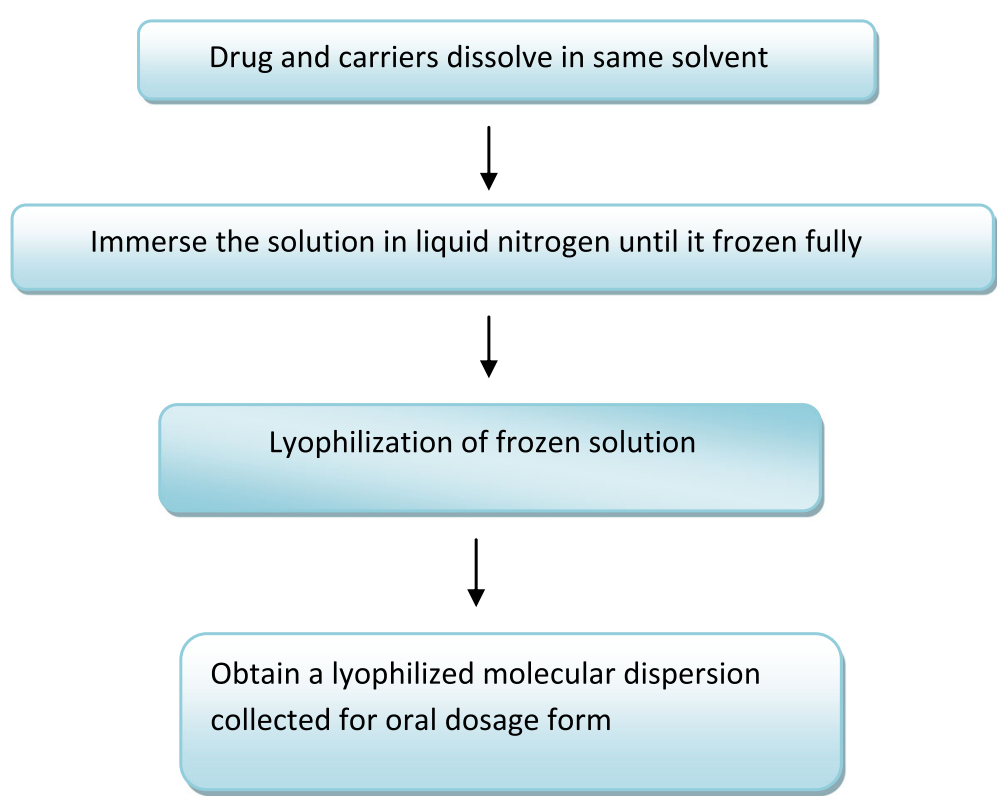

Fig. 9 Process of freeze drying

temperature when the carriers present in melting range or above that temperature (Fig. 7).

\subsubsection{Solvent evaporation}

Also known as solvent method in which solvent gets evaporated from drug and carrier solution and solid dispersion is formed. This method involves the volatile solvent that is able to dissolve the physical mixture of drug and carrier. Also, solvent contains low boiling point. The major advantage of this method is the thermal decomposition of drug and carriers is avoided at high temperature. Disadvantages: toxicity occurs due to difficulty in removal of residual solvent [25] (Fig. 8).

\subsubsection{Rotary evaporation [26]}

\subsubsection{Advantages}

1 Risk of phase separation is minimized.

2 Avoid the degradation of drug and carrier at high temperature.

For complete removal of residual solvent the final solid dispersion is stored in vacuum desiccator after solvent evaporation.

\subsubsection{Freeze drying [27]}

Another name of this method is lyophilization technique. The major advantage of this method is it decreases the chance of degradation of drug and phase

Drug and carrier solution were atomized into fine droplets

Sprayed it into a stream of heated gas flow for solvent removal

Fine solid dispersion particles

collected for oral dosage form

Fig. 10 Process of spray drying 


\section{Carrier and drug dissolved in supercritical carbon dioxide}

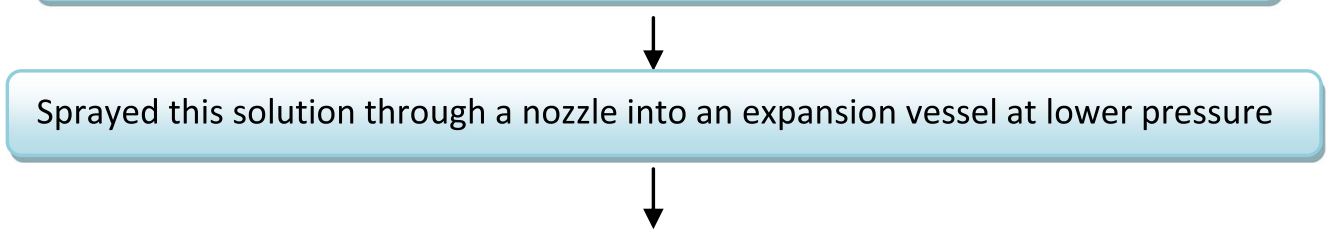

Rapid nucleation due to rapid expansion of dissolved drug and formation of solid dispersion particles collected for oral dosage form

Fig. 11 Process of SAS

separation because this method tries to operate at low temperature (Fig. 9).

\subsubsection{Spray drying [28]}

The most commonly known and more efficient method of solid dispersion is spray drying method having the major advantage like it avoid the phase separation and is able for formation of homogeneous systems (Fig. 10).

\subsubsection{Supercritical anti-solvent [SAS] [29]}

This is only one method which uses the carbon dioxide as a solubilizing solvent or anti-solvent in the preparation of solid dispersion (Fig. 11).

\subsubsection{Co-precipitation [30]}

This method involves drop wise addition of anti-solvent in the organic solution of drug and carriers. The major disadvantage of this method is that it avoids the risk of phase separation and degradation of drug due to avoiding the high temperature.

This method can be explained in Fig. 12.

\subsubsection{Electrostatic spinning [31]}

This method of solid dispersion is a technique which is formed by the combination of two techniques which are nanotechnology and solid dispersion technology, which in turn called as electrostatic spinning. The major advantage of this technology is rapid evaporation of solvent occur, due to the amorphous particles that are obtained which show highest dissolution (Fig. 13).

\subsubsection{Fluid bed coating [32]}

Fluid bed coating method uses drug and carrier dissolved in a suitable solvent, and this solution is atomized into fluid bed coater (Fig. 14).

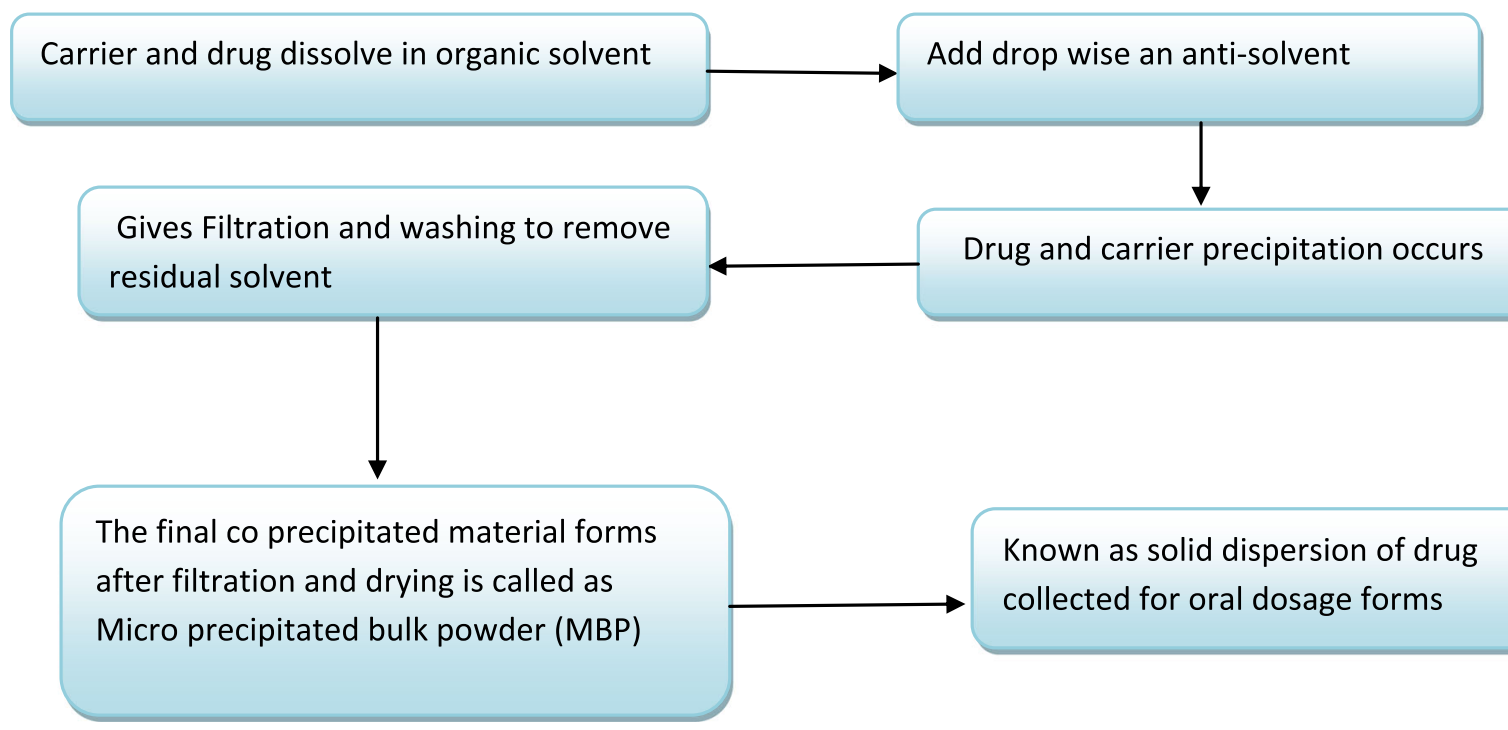

Fig. 12 Process of co-precipitation 


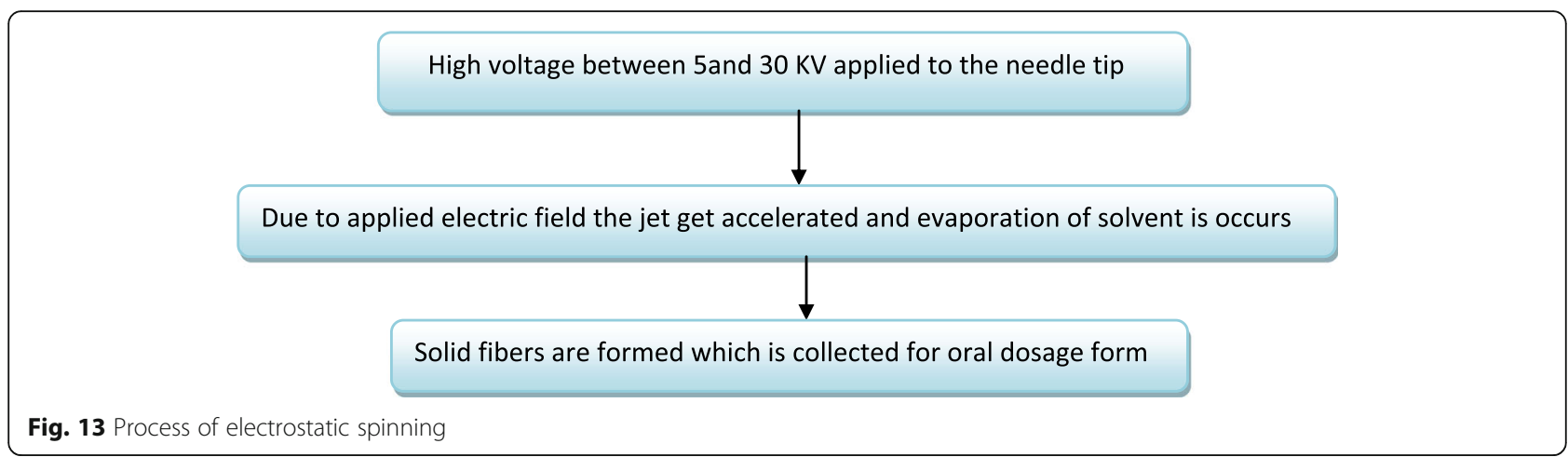

\section{Melting solvent method [33-35]}

Melting solvent method is a combination of solvent method and melting method. The major advantage of this technique is it avoids the risk of thermal degradation of drug (Fig. 15).

Recent study of oral dispersible tablets is shown in Table 2.

Promising therapeutic agents that can be incorporated in oral dispersible tablets are shown in Table 3.

\section{Evaluation parameters for oral dispersible tablet [80]}

Procedure for all evaluation parameter as follows:

\subsection{Evaluation of blends before compression}

The various characteristics of blends to be tested before compression are the following:

\subsubsection{Angle of repose}

Angle of repose is determined by using funnel method. The accurately weighed blend is taken in a funnel. The height of the funnel is adjusted in such a way that the tip of the funnel just touches the apex of the heap of blend. The drug (as solid dispersion) excipient blend is allowed to flow through the funnel freely on to the surface. The diameter of the powder cone is measured, and the angle of repose is calculated using the following equation:

$$
\operatorname{Tan} \Theta=\mathrm{h} / \mathrm{r}
$$

Where $h$ and $r$ are the height of cone and radius of cone base, respectively. Angle of repose less than $30^{\circ}$ shows the free flowing of the material.

\subsubsection{Bulk density}

Apparent bulk density is determined by pouring a weighed quantity of blend into graduated cylinder and measuring the volume and weight. Bulk density can be calculated by using following formula:

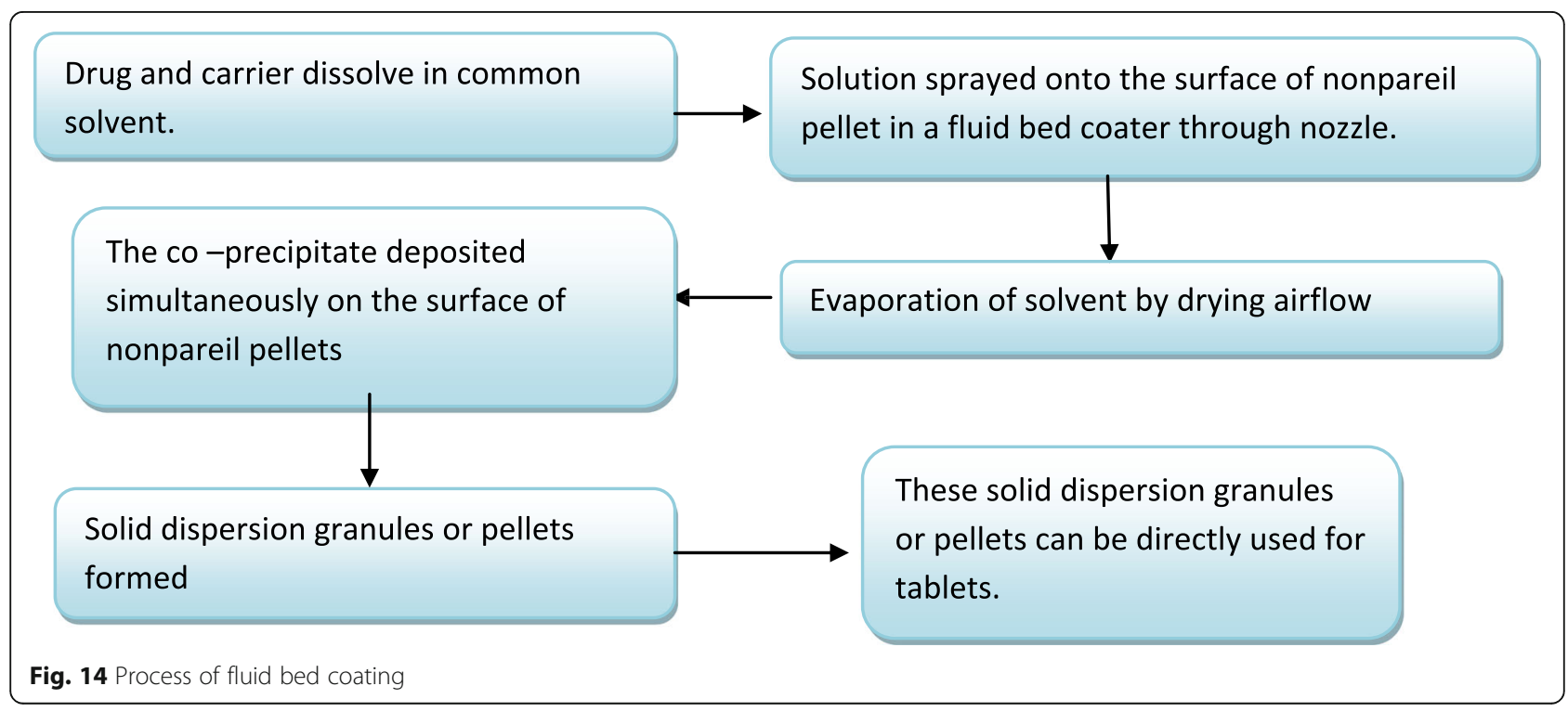




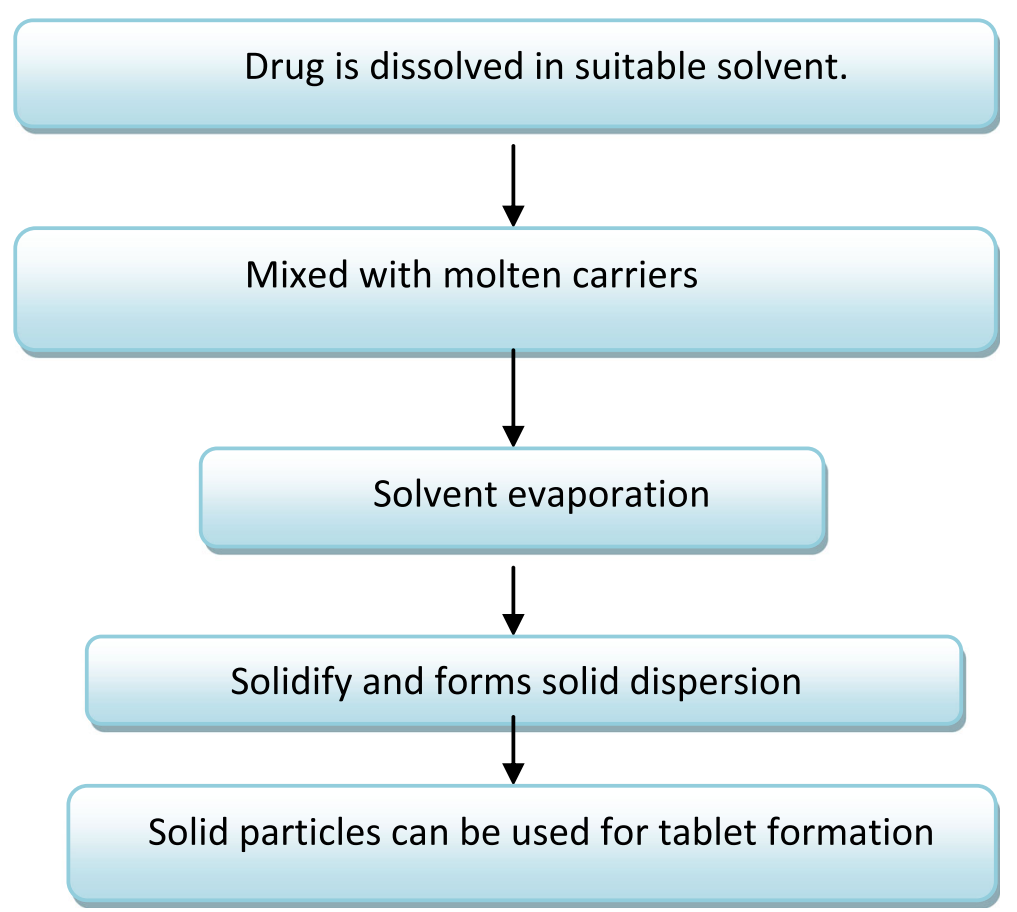

Fig. 15 Process of melting solvent method

Bulk density $=$ Weight of the powder/Volume of the packing

\subsubsection{Tapped density}

It is determined by placing a graduated cylinder, containing a known mass of drug-excipients blend. The cylinder is allowed to fall under its own weight onto a hard surface from the height of $10 \mathrm{~cm}$ at 2 $\mathrm{s}$ intervals. The tapping is continued until no further change in volume is noted. Tapped density can be calculated by using following formula:

Tapped Density $=($ Weight of the powder/volume of the tapped packing $)$

\subsubsection{Compressibility index}

The Compressibility Index of the blend is determined by compressibility index. Compressibility Index can be calculated by using following formula:

Compressibility Index $(\%)=[(\mathrm{TD}-\mathrm{BD}) \times 100] / \mathrm{TD}]$

\subsubsection{Hausner's ratio}

A similar index to indicate the flow properties can be defined by Hausner's ratio. Hausner's ratio can be calculated by using following formula:

Hausner's ratio $=($ Tapped density $\times 100) /($ Poured density $)$

Hausner's ratio
$<1.25$ - Good flow $=20 \%$ compressibility index

$>1.25$ - Poor flow $=33 \%$ compressibility index

\subsubsection{Void volume}

The volume of the spaces is known as the void volume " $V$ " and is given by the formula

$$
\mathrm{V}=\mathrm{Vb}-\mathrm{Vp}
$$

Where $\mathrm{Vb}$ = bulk volume (volume before tapping) $\mathrm{Vp}=$ true volume (volume after tapping)

\subsubsection{Porosity}

The porosity $€$ of powder is defined as the ratio of void volume to the bulk volume of the packaging. The porosity of the powder is given by following formula:

$$
€=\mathrm{Vb}-\mathrm{Vp} / \mathrm{Vp}=1-\mathrm{Vp} / \mathrm{Vb}
$$

Porosity is frequently expressed in percentage and is given as

$$
\% €=(1-\mathrm{Vp} / \mathrm{Vb}) \times 100
$$

The porosity of powder indicates the types of packaging a powder when subject to vibrations, when stored, or in tablet machine when passed through hopper or feed frame 
Table 2 Recent study of oral dispersible tablets

\begin{tabular}{|c|c|c|c|c|}
\hline $\begin{array}{l}\text { Sr. } \\
\text { no }\end{array}$ & Drug candidate & Carrier used & Solid dispersion technique used & $\begin{array}{l}\text { Ref. } \\
\text { no }\end{array}$ \\
\hline 1 & Lumacaft & HPMC & Spray drying & {$[4]$} \\
\hline 2 & Ritonavir & PVP & Melt extrusion & [4] \\
\hline 3 & Traconazole & HPMC & Melt extrusion & {$[4]$} \\
\hline 4 & lopinavir and ritonavir & PVP or polyvinyl acetate & Melt extrusion & {$[9]$} \\
\hline 5 & Torcetrapib & HPMC acetate succinate & Spray drying & {$[9]$} \\
\hline 6 & Ibuprofen & Various like starch 1500 PVP K 30 & Melt extrusion & {$[9,36]$} \\
\hline 7 & Verapamil & Various & Melt extrusion & [9] \\
\hline 8 & Troglitazone & PVP & Melt extrusion & {$[9]$} \\
\hline 9 & Tacrolimus & HPMC & Melt extrusion & [9] \\
\hline 10 & Etravirine & HPMC & Spray drying & [9] \\
\hline 11 & Everolimus & HPMC & Melt or spray drying & [9] \\
\hline 12 & Nifedipine & PVP or polaxomer & Melt or absorb on carrier & [9] \\
\hline 13 & Griseofulvin & PEG & Melt process & {$[9]$} \\
\hline 14 & Itraconazole & HPMC, Gelucire 50/13, compritol 888ATOO & Spray drying & {$[9,37]$} \\
\hline 15 & Nabilone & Providone & - & [9] \\
\hline 16 & Telaprevir & HPMC & Spray drying & [38] \\
\hline 17 & Nilvadipine & HPMC & Solvent evaporation method & {$[38]$} \\
\hline 18 & Vemurafinib & HPMC & Co-precipitation & [38] \\
\hline 19 & Ivacaftor & HPMC & Spray drying & {$[38]$} \\
\hline 20 & Tacrolimus & HPMC & Spray drying & [38] \\
\hline 21 & Everolimus & HPMC & Spray drying & [38] \\
\hline 22 & Silymarin & PVP K 17 & Supercritical fluid technology & {$[39]$} \\
\hline 23 & Polypeptide-K & Trehalose Tween 80 & Spray drying & [40] \\
\hline 24 & Valsartan & PEG 6000 HPMC-100 kV & Freeze drying & [41] \\
\hline 25 & Curcumin & Eudragit EPO & Solvent evaporation method & [42] \\
\hline 26 & Tadalafin & PVP, malic acid or meglumine and aerosil 200 & Solvent evaporation method & [43] \\
\hline 27 & $\begin{array}{l}\text { Pseudomonas podoviridine phase } \\
\text { PEV2 }\end{array}$ & Trehalose, mannitol, L-leucine & Spray drying & [44] \\
\hline 28 & Paracetamol & Ethyl cellulose, mesoporous silica & Fluid bed system & [45] \\
\hline 29 & Itraconazole & Sucrose & Centrifugal spinning method & [46] \\
\hline 30 & Olanzapine & Sucrose, pregelatinized starch, sodium starch, glycolate & Centrifugal spinning method & $\begin{array}{l}{[46,} \\
47]\end{array}$ \\
\hline 31 & Piroxicam & Sucrose & Centrifugal spinning method & [46] \\
\hline 32 & Atrovastatin & Mannitol, PEG 4000, PVP K 30 & $\begin{array}{l}\text { Hot melt and solvent evaporation } \\
\text { method }\end{array}$ & [48] \\
\hline 33 & Alprazolam & PEG 6000, PVP K 30 & Solvent evaporation & [49] \\
\hline 34 & Aceciofenac & Starch phosphate, Gelucire 50/13 & Kneading method & {$[50]$} \\
\hline 35 & Carvedilol & PEG 6000, Polaxomer407, HPMC, SSG & Fusion and solvent evaporation & [51] \\
\hline 36 & Cefdinir & PVP K 30, PEG 4000 & Melt fusion and solvent evaporation & {$[52]$} \\
\hline 37 & Diacerein & PVP K 30, HPMC & Solvent evaporation & [53] \\
\hline 38 & Etoricoxib & Lactose, sucrose, mannitol & Solvent evaporation & [54] \\
\hline 39 & Glipizide & HPMC, croscarmellose & Solvent evaporation & {$[55]$} \\
\hline 40 & Mefenamic acid & PEG 6000, PVP K 30, HPMC, MCC & Kneading method & {$[56]$} \\
\hline 41 & Nalidixic acid & PVP, beta cyclodextrin, SSG & Solvent evaporation method & {$[57]$} \\
\hline
\end{tabular}


Table 2 Recent study of oral dispersible tablets (Continued)

\begin{tabular}{|c|c|c|c|c|}
\hline $\begin{array}{l}\text { Sr. } \\
\text { no }\end{array}$ & Drug candidate & Carrier used & Solid dispersion technique used & $\begin{array}{l}\text { Ref. } \\
\text { no }\end{array}$ \\
\hline 42 & Rofecoxib & PEG 6000, PVP K 30 & $\begin{array}{l}\text { Fusion and solvent evaporation } \\
\text { method }\end{array}$ & {$[58]$} \\
\hline 43 & Simvastatin & PEG 4000, PVP K 30 & Solvent evaporation method & [59] \\
\hline 44 & Stranidazole & PEG 4000, PVP K 30 & Solvent evaporation method & [60] \\
\hline 45 & Meloxicam & PVP PEG 6000 & Solvent evaporation method & [61] \\
\hline 46 & Telmisartan & $\begin{array}{l}\text { Gelucire 43/01, polaxomer407, PVP-K 30, HPMC E4, PEG } \\
6000\end{array}$ & Fusion method & {$[62]$} \\
\hline 47 & Gliclazide & PEG 4000, PEG 6000, PVP K 30 & $\begin{array}{l}\text { Fusion and solvent evaporation } \\
\text { method }\end{array}$ & [63] \\
\hline 48 & Proglitazone & PEG 4000, PEG 6000, PEG 20000 & $\begin{array}{l}\text { Hot melt method } \\
\text { Microwave and kneading method }\end{array}$ & [64] \\
\hline 49 & Carbamazepine & Croscarmellose, SSG & Solvent evaporation method & [65] \\
\hline 50 & Mesalamine & SLS, urea, methanol & Kneading method & [66] \\
\hline 51 & Ketoprofen & PVP K 30, urea, mannitol, Tween 80 & Solvent evaporation method & {$[67]$} \\
\hline 52 & Indomethacin & Lactose monohydrate, PEG 6000, HPMC, povdone & Kneading method & [68] \\
\hline 53 & Clonazepam & PEG 6000, HPMC, polaxomer 407 & Solvent evaporation method & [69] \\
\hline 54 & Telmisartan & Beta cyclodextrin, MCC PH 102, polaxomer 188,400 & Solvent evaporation method & $\begin{array}{l}{[70,} \\
71]\end{array}$ \\
\hline 55 & Carvediol & Beta cyclodextrin, MCC PH 102, polaxomer 188 & Solvent evaporation method & [72] \\
\hline 55 & Chlorpheniramine maleate & PEG 6000 and SSG & Fusion method & [73] \\
\hline 56 & Nevirapine & Urea and PEG & Kneading method & [74] \\
\hline
\end{tabular}

\subsubsection{Evaluation of tablets}

All the formulated ODTs were subjected to the following quality control tests.

6.1.8.1 Weight variation The weight variation test is carried out in order to ensure uniformity in the weight of tablets in a batch. First, the total weight of 20 tablets from each formulation is determined and the average is calculated. The individual weight of the each tablet is also determined to find out the weight variation (Table 4).

6.1.8.2 Hardness The hardness of tablet is an indication of its strength. Measuring the force required to break the tablet across its tests. The force is measured in kilogram, and the hardness of about $3-5 \mathrm{~kg}$ / $\mathrm{cm}^{2}$ is considered to be satisfactory for uncoated tablets. Hardness of 10 tablets from each formulation is determined by Monsanto hardness tester, Pfizer hardness tester, etc.

6.1.8.3 Friability test Friability is the loss of weight of tablet in the container due to removal of fine particles from the surface. Friability test is carried out to access the ability of the tablet to withstand abrasion in packaging, handling, and transport. Roche friabilator is employed for finding the friability of the tablets. Weigh the 20 tablets from each batch and place in Roche friabilator that will rotate at 25 rpm for $4 \mathrm{~min}$. Dedust all the tablets and weigh again. The percentage of friability can be calculated using the formula:

$$
\% \text { Friability }=[(\mathrm{W} 1-\mathrm{W} 2) 100] / \mathrm{W} 1
$$

Where W1 = weight of tablet before test $\mathrm{W} 2$ = weight of tablet after test

6.1.8.4 Mechanical strength Tablets should possess adequate mechanical strength to bear shocks of handling in manufacturing, packaging, and shipping. Crushing strength and friability are two important parameters for the determination of mechanical strength. Crushing strength or tablet tensile strength is the force required to break a tablet by compression in the radial direction, and it is important to note that excessive crushing strength significantly reduces the disintegration time. The crushing strength of the tablet is measured by using Pfizer hardness tester. Tensile strength for crushing $(\mathrm{T})$ is calculated using equation 
Table 3 Promising therapeutic agents used in solid dispersion techniques [75, 76, 77, 78, 79]

\begin{tabular}{|c|c|c|}
\hline Sr. no & Agents & Examples \\
\hline 1 & Analgesics & Aloxipirin, auranofin, azapropazone \\
\hline 2 & Anthelmintics & Albendazole, bephenium hydroxynaphthoate, cambendazole \\
\hline 3 & Anti-arrhythmic agents & Amiodarone, disopyramide, flecamide acetate \\
\hline 4 & Anti-bacterial agents & Benethamine, penicillin, cinoxacin \\
\hline 5 & Anti-coagulants & Dicoumarol, dipyridamole, nicoumalone \\
\hline 6 & Anti-depressants & Amoxapine, ciclazindole, maprotiline \\
\hline 7 & Anti-epileptic & Beclamide, carbamazepine, clonazepam, ethotoin \\
\hline 8 & Anti-fungal & Amphotericin, butoconazole nitrate, clotrimazole, flucanazole \\
\hline 9 & Anti-gout & Allopurinol, probenecid, sulphinpyrazone \\
\hline 10 & Anti-hypertensive & Amlodipine, carvedilol, diltiazem, diazoxide, felodipine \\
\hline 11 & Anti-malarials & Amodiaquine, chloroquine, chlorproguanil, halofantrine, mefloquine \\
\hline 12 & Anti-migraine & Dihydroergotamine mesyiate, ergotamine tetrate, methysergide \\
\hline 13 & Anti-neoplastic and immunosuppresant & Busulphan, chlorambucil, cyclosporin \\
\hline 14 & Anti-protozoal & Benzindazole, decoquinate, diiodohydroxyquinoline \\
\hline 15 & Anti-thyroid & Carbimazole, propylthioouracil \\
\hline 16 & Anxiolytic, sedatives, hypnotics, and neuroleptics & Alprazolam, amyiobarbitone \\
\hline 17 & Cardiac ionotropic & Amrinone, digitoxin, digoxin, lantoside $C$ \\
\hline 18 & Corticosteroids & Beclomethasone, betamethasone, budesonide, cortisone acetate \\
\hline 19 & Diuretics & Acetazolamide, amiloride, bumetanide, chiorothiazide \\
\hline 20 & Enzymes & All the enzymes \\
\hline 21 & Anti-Parkinsonian & Bromocriptine mesylate, lysuride maleate \\
\hline 22 & Gastro-intestinal & Bisacodyl, cimetidine, domperidone, famotidine \\
\hline 23 & Histamine H-receptor antagonist & Acrivastine, astemizole, cinnarizine, cyclizine \\
\hline 24 & Lipid regulating & Bezafibrate, clofibrate, fenofibrate, gemfibrozil \\
\hline 25 & Local anesthetics & Lidocaine \\
\hline 26 & Neuro-muscular & Pyridostigmine \\
\hline 27 & Nitrates and other anti-anginal & Amyl nitrate, glyceryl trinitrate \\
\hline 28 & Nutritional & Betacarotene, vitamin $A$, vitamin $B 2$, vitamin $D$, vita $E$ \\
\hline 29 & Opioid analgesics & Codeine, diamorphine, dihydrocodeine, meptazinol \\
\hline 30 & Oral vaccines & Influenza, tuberculosis, hepatitis, polio, tetanus \\
\hline 31 & Proteins and peptides & Insulin, glucagon, growth hormone \\
\hline 32 & Stimulants & Amphetamine, dexamphetamine, dexfenfluramine, fenfluramine, pemoline \\
\hline
\end{tabular}

Table 4 Standard limit of weight variation

\begin{tabular}{llll}
\hline Sr. no. & IP/BP & Limit & USP \\
\hline 1 & $80 \mathrm{mg}$ or less & $10 \%$ & $130 \mathrm{mg}$ or less \\
2 & $80 \mathrm{mg}$ to less than $250 \mathrm{mg}$ & $7.5 \%$ & $130 \mathrm{mg}$ to $324 \mathrm{mg}$ \\
3 & $250 \mathrm{mg}$ or more & $5 \%$ & More than $324 \mathrm{mg}$ \\
\hline
\end{tabular}

$$
\mathrm{T}=2 \mathrm{~F} / \pi * \mathrm{~d} * \mathrm{t}
$$

Where $F$ is the crushing load, and $d$ and $t$ denote the diameter and thickness of the tablet respectively.

6.1.8.5 Uniformity of dispersion Keep the two tablets in $100 \mathrm{ml}$ water and stir gently for $2 \mathrm{~min}$. The dispersion is passed through 22 meshes. The tablets will be considered to have passed the test if no residue remained on the screen.

6.1.8.6 Wetting time The wetting time of the tablets is measure by using a simple procedure. Place five circular 
tissue papers of $10 \mathrm{~cm}$ diameter in a Petri dish containing $0.2 \% \mathrm{w} / \mathrm{v}$ solution $(3 \mathrm{ml})$ of water-soluble dye. A tablet is carefully placed on the surface of the tissue paper. The time required for water to reach upper surface of the tablet is noted as the wetting time.

6.1.8.7 Water absorption ratio A small piece of tissue paper folded twice is placed in a small Petri dish containing $6 \mathrm{ml}$ of water. Put a tablet on the paper and the time required for complete wetting is measured. The wetted tablet is then reweighed. Water absorption ratio, $R$, is determined by using following formula:

$$
\mathrm{R}=100 \times \mathrm{Wa}-\mathrm{Wb} / \mathrm{Wb}
$$

Where $\mathrm{Wb}$ is the weight of tablet before water absorption

Wa is the weight of tablet after water absorption.

6.1.8.8 Taste/mouth sensation Mouth-feel is critical, and patients should receive a product that feels pleasant. One tablet from each batch is tested for the sensation by placing the tablet on the tongue. The healthy human volunteers are used for evaluation of mouth feel. Taste evaluation is done by a panel of 5 members using time intensity method. Sample equivalent to $40 \mathrm{mg}$, i.e., dose of drug is put in mouth for $10 \mathrm{~s}$ and record taste instantly and then after $10 \mathrm{~s}, 1,2,4$, and $6 \mathrm{~min}$. Volunteer's opinion for the taste is rated by giving different score values, i.e., $0=$ good, $1=$ tasteless, $2=$ slightly bitter, 3 = bitter, 4 = awful.

6.1.8.9 In vitro disintegration test In vitro disintegration time is measured by dropping a tablet in a beaker containing $50 \mathrm{ml}$ of Sorenson's buffer pH 6.8. Three tablets from each formulation are randomly selected and in vitro disintegration test is carried out.

6.1.8.10 In vitro dissolution test In vitro dissolution study is performed by using USP Type II Apparatus (Paddle type) at $50 \mathrm{rpm}$. Phosphate buffer $\mathrm{pH} 6.8,900$ $\mathrm{ml}$ is used as dissolution medium which maintained at $37 \pm 0.5{ }^{\circ} \mathrm{C}$. Withdraw aliquot of dissolution medium $(10 \mathrm{ml})$ at specific time intervals $(2 \mathrm{~min})$ and filter. The amount of drug dissolved is determined by suitable analytical technique.

6.1.8.11 Stability studies The optimized formulation of ODTs is subjected to stability study as per ICH guidelines to assess their stability with respect to their physical appearance and release characteristics.

6.1.8.12 Differential scanning calorimetry (DSC) [81] DSC measurement were carried out using a Perkin/
Elmer, Pyris DSC instrument (Norwalk, USA). Approximately $5 \mathrm{mg}$ of sample was analyzed at a heating rate of $5{ }^{\circ} \mathrm{C} / \mathrm{min}$ from 50 to $250{ }^{\circ} \mathrm{C}$ (or $230{ }^{\circ} \mathrm{C}$ ). After cooling to $20{ }^{\circ} \mathrm{C}$, the sample was reheated to $250{ }^{\circ} \mathrm{C}$ (or $230{ }^{\circ} \mathrm{C}$ ) at the same heating rate as used in the first cycle. The analysis was made in duplicate $(\mathrm{n} / 2)$ in vented aluminum pans, under nitrogen purge. Indium was used to calibrate enthalpy and temperature.

\section{Conclusion}

Therapeutic activity of drug mainly depends on the bioavailability of the drug and ultimately depends on the solubility. Solid dispersion is one of the most important techniques to increase solubility, dissolution, and bioavailability of drug. Oral dispersible tablet have significant advantage of immediate conversion of solid to liquid after administration. The development of oral dispersible tablet by solid dispersion also provides an opportunity for a line extension in market place, for wide range of drugs. Keeping in view the advantages of the delivery system, rapidly disintegrating dosage forms have been successfully commercialized, and because of increased patient demand, these dosage forms are expected to become more popular.

\section{Abbreviations}

ODT: Oral dispersible tablets; DSC: Differential scanning calorimetry; ICH: International conference harmonization; USP: United State Pharmacopoeia; SAS: Supercritical anti-solvent

\section{Acknowledgements}

The authors are thankful to the management of Amrutvahini College of Pharmacy, Sangamner, Maharashtra-422608 affiliated to Savitribai Phule Pune University, India, for providing the necessary facilities to carry out this work.

\section{Authors' contributions}

VKN is the first author contributing in writing of manuscript and gives their scientific suggestion. SKS is the second author contributing in collection of information and writing of manuscript. JPK is the third author contributing in grammatically molding of manuscript. All authors have read and approved the manuscript.

Funding

Any type of funding for this review is not available.

\section{Availability of data and materials}

Data will not be shared because of its review article, so there is no practical data available apart from manuscript and their references.

Ethics approval and consent to participate

Not applicable

Consent for publication

Not applicable

\section{Competing interests}

The authors declare that they have no competing interests.

Author details

${ }^{1}$ Amrutvahini College of Pharmacy, Sangamner, MS 422 608, India. ${ }^{2}$ Dr.

Naikwadi College of Pharmacy, Jamgaon, Sinner, MS 422 103, India. 
Received: 23 May 2020 Accepted: 16 November 2020 Published online: 09 December 2020

\section{References}

1. Saritha AS, Santhosh RI (2015) Fast dissolving tablets using solid dispersion technique: an overview. Indo Am J Pharma Res 5(2):668-679

2. Hannan PA, Khan JA, Khan A, Safiullah S (2017) Oral dispersible systems: a new approach in drug delivery system. Ind J Pharm Sci 78:2-7

3. Pratik SD, Sushma V, Puja S (2017) Fast dissolving tablet using solid dispersion technique: a review. Int J Current Pharm Res 9(6):1-4

4. BhaskarR MO, Ravindra MG (2018) Review: solid dispersion techniques for enhancement of solubility of poorly soluble drug. Ind. J. Pharma Bio Res 6(2):43-52

5. Kumar B (2017) Solid Dispersion: A Review. Pharm Tutor 5(2):24-29

6. Sultana S, Saifuddin AHM (2016) Solid Dispersion: currently practiced in pharmaceutical field. Int. J. Adv Res Technol. 5(3):170-175

7. Mathew G, Lincy J, Pooran Mal S, Jyothilakshmi VN (2016) Research article on enhancing the bioavailability of poorly water soluble drug etoroxib using solid dispersion technique - solid dispersion a method to improve bioavailability of poorly water soluble drug. Int. J. Pharma Pharma. Res. 6(4): $17-51$

8. Allen LV, Levinson RS, Martono DD (1978). Dissolution Rates of Hydrocortisone and Prednisone utilizing sugar solid dispersion systems in tablet form. J. Pharm. Sci 67(7):979-981

9. Das SK, Roy S, Yuvaraj K, Khanam J (2011) Solid dispersion : an approach to enhance the bioavailability of poorly water soluble drugs. Int. J. Plastic Poly. Technol. 1(1):37-46

10. Leunner C, Dressman J (2000) Improving drug solubility for oral delivery using solid dispersions. Eur. J. Pharm. Biopharm 50(1):47-60

11. Ramesh V, Meenakshi S, Jyothirmayee N, Bullebbai M, Noorjahan SK, Rajeswari G, Nagesh Babu G, Madhavi D (2016) Enhancement of solubility, dissolution rate and bioavailability of BCS Class II Drugs. Int J Pharma Chem Res 2(2):80-95

12. Ghaderi R, Artursson P, Carlfors J (1996) Preparation of biodegradable microparticles using solution-enhanced dispersion by supercritical fluids (SEDS). Pharm. Research 16(5):676-681. https://doi.org/10.1023/A: 1018868423309

13. Vasconcelos T, Sarmento B, Costa P (2007) Solid dispersions as strategy to improve oralbioavailability of poor water soluble drugs. Drug Discov. Today 12(23-24):1068-1075. https://doi.org/10.1016/j.drudis.2007.09.005

14. Pokharkar VB, Mandpe LP, Padamwar MN, Ambike AA, Mahadik KR, Paradkar A (2006) Development, characterization and stabilizationof amorphous form of a low Tg drug. Powder Technol 167(1):20-25. https://doi.org/10.1016/j. powtec.2006.05.012

15. Taylor LS, Zografi G (1997) Spectroscopic characterization of interactions between PVP and indomethacin in amorphous molecular dispersions. Pharm Res 14(12):1691-1698. https://doi.org/10.1023/A:1012167410376

16. Arias M J, Gines JM, Moyano JR, Rabasco AM. The application of solid dispersion technique withD-mannitol to the improvement in oral absorption of triamterene. J. Drug Target 2(1):45-51.

17. Sandip RP, Shashikant DE (2019) Solubility enhancement (Solid Dispersion) novel boon to increase bioavailability. J Drug Delivery Therapeutics 9(2): 583-590

18. Mohd AF, Dilip KP, Kesharwani R (2018) A technique to enhance the bioavailability and solubility for poorly water soluble drugs by using solid dispersions. World J Pharm Pharm. Sci. 7(11):818-836

19. Younis AM (2017) Solid dispersion technology, a contemporary overview on a well-established technique. Uni. J. Pharm. Res. 2(3):2456-8058

20. Debjit BM, Chiranjib JJ, Vinod D, Margret C (2009) Fast dissolving tablet: a Review on revolution of novel drug delivery system and new market opportunities. Sch. Res. Library 1(2):262-276

21. Singh (2017) Solubility enhancement by solid dispersion. Ind. J. Pharm. Sci 79(5):674-687

22. Ramesh V, Meenakshi S (2016) Enhancement of solubility for poorly water soluble drugs by using solid dsipersion technology. Int. J. Pharm. Res BioSci. 5(2):47-74

23. Allawadi D, Singh N, Singh S. And Arora S(2013). Solid dispersions: a review on drug delivery system and solubility enhancement. Int. J. Pharm. Sci. Res. 4(6):2094.

24. Singh J, Walia M. And Harikumar SL (2013). Solubility Enhancement by Solid Dispersion Method: A Review. J. Drug Delivery Therapeutics 3(5):148-155.
25. Midha, K., Rani, P. And Arora, G(2017). Solid dispersion: a recent update. Int J Pharm Pharmacol 1:104.

26. Vasconcelos T, Sarmento B. And Costa P (2007).Solid dispersions as strategy to improve oral bioavailability of poor water soluble drugs. Drug Discov. Today 12(23-24):1068-1075.

27. Katariya VR, Patil SB (2013) Recent breakthroughs in solid dispersion: a review. Int. J. Pharm. Res. Allied Sci. 2(4):1-15

28. Vo CLN, Park C, And Lee BJ (2013) Current trends and future perspectives of solid dispersions containing poorly water-soluble drugs. Eur. J. Pharm Biopharm. 85(3):799-813

29. Baghel S, Cathcart H. And Oreilly NJ (2016). Polymeric amorphous solid dispersions: a review of amorphization, crystallization, stabilization, solid state characterization, and aqueous solubilization of biopharmaceutical classification system class II drugs. J. Pharm. Sci. 105(9):2527-2544.

30. Bikiaris DN (2011) Solid dispersions, part i: recent evolutions and future opportunities in manufacturing methods for dissolution rate enhancement of poorly water-soluble drugs. Expert Opinion on Drug Delivery 8(11):1501-1519

31. Dixit ND, Niranjan SK (2014) A review: solid dispersion. World J. Pharm Pharm. Sci. 3(9):238-257

32. Kaur T, Gill B, Kumar S, Gupta GD (2011) Mouth dissolving tablets: a novel approach to drug delivery. Int. J. Curr. Pharm. Res. 1:1-7

33. Nagar P, Singh K, Chauhan I, Verma M, Yasir M, Khan A (2015) Orally disintegrating tablets: formulation, preparation techniques and evaluation. J. Appl. Pharm. Sci. 4:35-45

34. Kumaresan C (2015) Orally disintegrating tablet-mouth dissolving, sweet taste and target release profile. Pharmaceutical 6:25-36

35. Eun JK (2016) Preparation of solid dispersion of felodipine using a solvent wetting method. Eur. J. Pharm. Biopharm. 64:200-205

36. Shivalingam MR, Jyothibasu T, Kishore $\mathrm{W}$, Reddy A, Tejaswi B, Nagaanusha D (2011) Formulation and evaluation of solid dispersions of glipizide for dissolution rate enhancement. Int. J. Pharma. Res. Dev. 3(23):231-239

37. Prasad RS, Sarath KY, Manavalan R (2010) Preparation and characterization of itraconazole solid dispersions for improved oral bioavailability. Int. J. Chem. Tech. Res. 2(1):133-142

38. Kazi PA, Gholve SB, Kazi SN (2014) Review article solid dispersion: an evergreen method for solubility enhancement of poorly water soluble drugs. Int. J. Res. Pharm. Chem. 4:906-918

39. Sabitari B, Snehamayee M (2018) Recent research of solid dispersion: a new concept towards oral bioavailability. Asian J. Pharm. Clinical Res. 11(2):72-78

40. Gang Y, Zhao Y, Feng N, Zhang Y, Liu Y, Dang B (2015) Improved dissolution and bioavailability of silymarin delivered by a solid dispersion prepared using supercritical fluids. Asian J. Pharm. Sci. 10:194-204

41. Kaur P, Singh SK, Garg V, Gulati M, Vaidya Y (2015) Optimization of spray drying process for formulation of solid dispersion containing polypeptide-k powder through quality by design approach. Powder Technol. 284:1-11

42. Wei-Juan X, Xie HJ, Cao QR, Shi LL, Clao Y, Zhu XY (2016) Dissolution and oral bioavailability of valsartan solid dispersions prepared by a freeze-drying technique using hydrophilic polymer. J. Drug Delivery 23:41-48

43. Li J, Lee IW, Shin GH, Chen X, Park HJ (2015) Curcumin-eudragit ${ }^{\oplus}$ E PO solid dispersion: A simple and potent method to solve the problems of curcumin. Eur. J. Pharm. Biopharm. 94:322-332

44. Choi JS, Park JS (2015) Design of PVPNA S-630 based tadalafil solid dispersion to enhance the dissolution rate. Eur. J. Pharm. Sci 97:269-276

45. Hacene YC, Singh A, Mooter GV (2016) Drug loaded and ethylcellulose coated mesoporous silica for controlled drug release prepared using a pilot scale fluid bed system. Int. J. Pharm. 506:138-147

46. Leung SS, Parumasivam T, Gao FG, Carrigy NB, Vehring R, Finlay WH (2016) Production of inhalation phage powders using spray freeze drying and spray drying techniques for treatment of respiratory infections. J. Pharm. Res 33:1486-1496

47. Rao P, Nagabhushanam MV, Prabhakar CH (2011) Enhancement of dissolution rate of poorly soluble drug mefenamic acid by solid dispersion. Res. J. Pharm. Bio. Chem. Sci. 2(3):1025-1035

48. Marano S, Barker SA, Raimi-Abraham BT, Missaghi S, Rajabi-Siahboomi A Aliev AE (2017) Microfibrous solid dispersions of poorly water-soluble drugs produced via centrifugal spinning: Unexpected dissolution behavior on recrystallization. Mol. Pharm. 14:1666-1680

49. Bobe KR, Subrahmanya CR, Sarasija S, Gaikwad DT, Patil MD, Khade TS, Gavitre B, Kulkarni VS, Gaikwad UT (2011) Formulation and Evaluation of Solid Dispersion of Atorvastatin with Various Carriers. Int. J Comprehensive Pharma. 2(1):1-6 
50. Roul LK, Manna NK, Parhi RN, Sahoo S, Suresh P (2012) Dissolution rate enhancement of alprazolam by solid dispersion. Ind. J. Pharm. Edu. and Res. 46(1):38-44

51. KPR. Chowdary KR, Kvnr. Aishwarya and Adilakshmi (2012). A factorial study on the enhancement of dissolution rate of aceclofenac by solid dispersion in starch phosphate and gelucire. Int. J Res Pharma. Chem.2(4):907-912.

52. Irin Dewan MD. Ayub H and Ashraful Islam SM (2012). Formulation and evaluation of solid dispersions of carvedilol, a poorly water soluble drug by using different polymers. Int. J Res Pharma. Chem. 2(3):585-593

53. Kumar P, Kumar S, Kumar A, Chander M (2010) Physicochemical characterization of solid dispersions of cefdinir with Pvp K-30 and Peg 4000 Int. J. Pharm. Sci Nanotechnol. 3(2):948-956

54. Deshmukh DB, Gaikwad PD, BankarVH PSP (2010) Dissolution enhancement of poorly water soluble diacereinby solid dispersion technique. J Pharm Sci Res 2(11):734-739

55. Abhisekh D, Amit Kumar N, Biswaranjanmohanty, and Satyabrata P (2011). Solubility and dissolution enhancement of etoricoxib by solid dispersion technique using sugar carriers. Int. Scholarly Res. Network Isrn Pharm. Article id 819765:1-8.

56. Chowdary KPR, Udaya Chandra D, Parimala V And Indira M (2012). A factorial study on formulation development of ibuprofen tablets employing starch 1500 and Pvp K 30. Int J Pharm Sci Res 3(1):189-193.

57. Subrata M, Ashok S, Kaushik P (2004) Dissolution behaviour of nalidix acid solid dispersions using water soluble dispersion carriers. Acta Poloniae Phrma. -Drug Res 61:21-30

58. Venkateskumar K, Arunkumar N, Verma P, Ranjan P, Siva P, Neema GAnd Punitha K (2011) Characterization of olanzapine-solid dispersions. Iran. J. Pharm. Res. 10(1):13-24

59. Vyas J, Vyas P, Patel J (2011) Formulation and evaluation of solid dispersions of rofecoxib for improvement of dissolution profile. Afr J. Pharm Pharmacology 5(5):577-581

60. Sukanya M, Sai Kishore V (2012) Design and development of solid dispersions of simvastatin for enhancing the solubility. Am J. Pharma. Tech. Res. 2(4):733-740

61. Dhat SP, Aphale SA, Sherje AP, Sakale JA, Vaidya AV, Vanshiv SD (2011) Solubility enhancement of satranidazole using solid dispersion technique. Int. J. Res. Pharm. Biomedical Sci. 2(3):1134-1135

62. Mohammed J, Dehghan M, Adil S (2010) Enhancementof dissolution and anti-inflammatory effect of meloxicam using solid dispersions. Int. J. Applied Pharm. 2(1):1-8

63. Sucheta B, Dyandevi M, Mithun VKP, Rajendra DP (2011) Solubility enhancement of antihypertensive agent by solid dispersion technique. International Journal of Pharmacy \& Life Sciences. Int. J. Of Pharm Life Sci. 2(8):970-975

64. Gopal Venkatesh S, Averineni Ranjith K, Yogendra Nayak U, Karthik A, Om Prakash R, Kishore G, Sureshwar P, Nayababhirama U (2010) Enhanced dissolution and bioavailability of gliclazide using solid dispersion techniques. Int. J. Drug Delivery 2:49-57

65. Vinay P, Roopa SP, Kusum D, Saraija S (2012) In vitro-in vivo evaluation of fast-dissoliving tablets containing solid dispersion of pioglitazone hydrochloride. J. Adv. Pharm. Tech Res. 3(3):160-165

66. Renu K, Stuti G, Rajendra KRS, Dolly J, Sushma P (2011) Study of enhancement of dissolution rate of carbamazepine by solid dispersion. Int. J. Compr. Pharm. 5(9):1007-1014

67. Lalit J, Tapar KK (2011) Preparation and characterization of mesalamine solid dispersions by kneading method. Int. J. Pharm. Sci Res. 2(10):2623-2628

68. Nashwan YK, Alaaa A, Moafaq MG, Saad AH (2011) Solubility and dissolution improvement of ketoprofen by solid dispersion-polymer and surfactant using solvent evaporation method. Int. J. Pharm Pharm. Sci. 3(4):431-435

69. Yadav YB And Yadav AV (2009) Indomethacin solid dispersions by kneading method with lactose monohydrate and different polymers. J.Pharm. Res. 2(9):1489-1492.

70. Minhaz RA, Mofizur MD, Ahsan Q, Rahman H, Chowdhury R (2012) Enhancement of solubility and dissolution properties of clonazepam by solid dispersions. Int. J. Pharm. Life Sci. 3(3):1510-1515

71. Ramesh V, Rukesh KJ, Chowdary KPR (2015) Formulation of Telmisartan tablets employing solid dispersions in MCC PH102 and Poloxamer188 as per 22 factorial design. World J. Pharm. Res. 4(12):1397-1405

72. Ramesh V, Rukesh KJ, Chowdary KPR (2015) Formulation of Carvedilol tablets employing solid dispersions in MCC PH102 and Poloxamer188 as per 22 factorial design. World J. Pharm. Pharm. Sci. 5(2):753-762
73. Vivek D, Renu BY, Richa A, Atul KS (2017) Formulation and evaluation of orally dispersible tablets of Chlorpheniramine maleate by fusion method. Marmara Pharm. J 21:67-77. https://doi.org/10.12991/marupj.259883

74. Balasubramanian VM, Shaik AR, Kenneti NM, Muuva A, Nadendla RR (2017) Formulation and evaluation of mouth dissolving tablets of telmisartan by solid dispersion technique. Asian J. of Res. Chem Pharm. Sci. 5(1):38-49

75. Singh G, Kaur L, Gupta GD (2017) Enhancement of the solubility of poorly soluble drugs through solid dispersion: A comprehensive review. Ind. J. Pharm. Sci. 79(5):674-687

76. Allen LVJ, Yanchick VA, Maness DD (1997) Dissolution rates of corticosteriods utilizing sugar glass dispersions. J. Pharm. Sci 66(4):494-496

77. Ratnaparkhil MP, Mohanta GP, Upadhyay L (2009) Review on: Fast Dissolving Tablet. J. Pharm. Res. 2(1):5-12

78. Amidon GL, Lennernas H, Shah VP, Crison JR (1995) Theoretical basis for a biopharmaceutic drug classification the correlation of in vitro drug product dissolution and in vivo bioavailability. Pharm. Res. 3(12):413-420

79. Shaik AR (2015) Pharmaceutical drug classification: the correlation of in vitro drug product dissolution and in vivo bioavailability. Pharm Res. 12(3):413420

80. Shyamala B, Narmada GY (2002) Rapid dissolving tablets: a novel dosage form. The Ind. Pharmacist. 13(8):09-12

81. Anne MJ, Catherine B, Cynthia K (2003) Evaluation of solid dispersion particles prepared with SEDS. Int. J. of Pharm. 250:385-401

\section{Publisher's Note}

Springer Nature remains neutral with regard to jurisdictional claims in published maps and institutional affiliations.

\section{Submit your manuscript to a SpringerOpen ${ }^{\circ}$ journal and benefit from:}

- Convenient online submission

- Rigorous peer review

- Open access: articles freely available online

- High visibility within the field

- Retaining the copyright to your article

Submit your next manuscript at $>$ springeropen.com 